\title{
Development of the Processing Procedure for Palm Fiber with Communities for Industrial Handmade Product Creation
}

\author{
Songwut Egwutvongsa*
}

\author{
Somchai Setvisat
}

Thanat Pirumgran

\author{
Department of Architectural Education and Design, \\ King Mongkut's Institute of Technology Ladkrabang, \\ Bangkok, Thailand \\ *Corresponding Author
}

DOI: https://doi.org/10.36941/ajis-2021-0071

\begin{abstract}
This research used a mixed-methods approach to focus on the properties and satisfaction assessment of effectiveness for palm fibers in the Khonsan Sub-District community group in Chaiyaphum province with a total of 113 people. In addition, the study used a 5-point rating scale which had a Cronbach's Alpha Coefficient value at the level of 0.97 , in addition to two-way ANOVA. The study presented testing results by ordering from coconuts, palms, betel nuts, and tans with the fiber tensile ratings of $67.45 \mathrm{~N}, 57.19 \mathrm{~N}, 56.75 \mathrm{~N}, 52.49 \mathrm{~N}$, and fiber tensile ratings of $6.80 \%, 7.30 \%, 7.12 \%$, and $6.25 \%$, respectively. In this case, the betel nut fibers and tan fibers showed durability to wet washing and the dry period as the most common way. Thus, the satisfaction assessment of tan fibers was at the most satisfactory level, (Mean=4.49, S.D. $=0.57$ ), followed by the coconut fibers at the excellent level, (Mean $=4.47$, S.D. $=0.56)$ and the betel nut fibers at the moderate level, (Mean=3.35, $S . D .=0.71)$. Levene's test showed that $p$ was equal to o.oo, indicating that the factors of type and properties of palm fibers were at a varied level with statistical significance. Similarly, the fiber characteristics and properties of palm fibers for each type had an F value equal to 11.45 and Sig. equal to o.oo. In addition, it was found that there was at least one pair different from other pairs, such as coconut fibers and tan fibers. Consequently, the research with community participation showed that it appeared to confirm the balance between the effectiveness of materials, labor skills, human labor, and the stabilization of life. As a result, it affected the satisfaction at the excellent level for people in the development communities (Mean=4.10, S.D. =0.78).
\end{abstract}

Keywords: Designing, Products, Fibers, Sugar palm, Green products

\section{Introduction}

Thailand is considered a country that is self-reliant in terms of its agriculture, which accounts for more than 40 percent of the economic activity in the country. Besides, the country has a large area to cultivate for commercial plants such as palms, betel nuts, tans, and others. Similarly, fluctuations appear in the sales trends for palm family fruits with the reducing trends continuously affecting price, therefore leading to a reduction in production. In such a case, this results in oil palm problems in 
Thailand as the reducing trends result in a high level of price fluctuation for the markets (Al-Khayri \& Niblett, 2012). This affects the stability and sustainability of Thai farmers' lifestyles based on the lowest mean level of the oil palm production prices, as seen in 2018 for Thailand. This case represented the lowest price in 17 years with a price level of 1.91-2.12 baht per kilo (Office of Agricultural Economics. 2018). While the government sector supported the Electricity Generating Authority of Thailand to purchase raw oil palm for electricity generation within the country, this still did not result in the right balance of quantity and oil palm production price in the markets (Buranasing, 2015). Instead, it contributed to the excessive quantity of palm fruits, reaching 17 million tons each year for harvesting until an oversupply problem was created. As a result, this problem eventually became one of selling prices, directly affecting the lifestyles of those working in agriculture by having a severe effect on incomes, leading to instability in farmers' living standards.

Because of the price effects and the selling quantities from palm family production with the continuous decreasing trends such as coconuts, tans, and betel nuts with fewer customers, it contributed to the cultivation areas of these plants decreasing by 2.53-4.76 percent each year. Besides, the cultivation of the palm family has taken an uncertain direction at present as farmers look for more stable income sources through planting. The problem is that farmers who always cultivate only plants from the palm family and rely on this production as their main source of income will cause the nonstabilization of their incomes and lives. The farmers will then begin a new trend to increasingly cancel the cultivation of the palm family, especially where they have a lower consumption ratio for certain palm family types, such as tans, betel nuts, oil palm plants, and coconut plants. Similarly, the declining prices of these plants result in the realization by the farmers to cut plant cultivation by less than $20 \%$ per year due to the poor situation from sale prices.
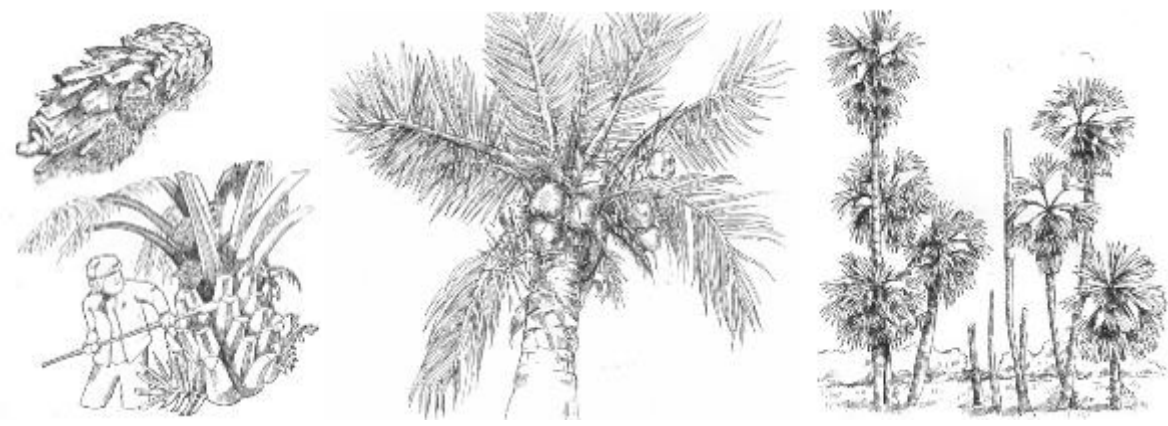

Fig. 1: Palm family plants in Thailand

Source: Author

This decision amounts solely to the end problem. Thus, there should be guidelines to consider for solutions by using the odd utilization pattern method based on originality. In the same way, it can focus on the increasing ratios of economic values with environmental friendliness by using the palm family fibers by considering all of their invaluable parts, which can be used beneficially and sustainably with examples including bunches and leaf stalks (Na Takuathung et al., 2015; John Karkazis \& Georgios C. Baltos, 2018).

It can be developed with the transforming procedure for the fibers to add economic value by using the creative guidelines for palm fibers to develop the commercial handmade product design. In this case, it is suitable for the effectiveness of the local area and communities through the participation of people or agriculturists in the area. Thus, it is considered a sustainable solution for the system. Significantly, the analysis of the requirement trends from the environmental product marketing group showed increasing growth with the market expanding into the new generation, who will demand more green products in greater variety. This includes the growing trends of the consumer and manufacturing 
groups (Ittarachuto, 2009). Currently, society tends to place importance on development using the characteristics of eco-innovation, increasingly by focusing on positive environmental effects with sustainability. Thus, products that represent environmental innovation and uniqueness can contribute to the likelihood of success between products and customers whose attitudes these days favor environmental responsibility.

\section{Methodology}

\section{$2.1 \quad$ Research Objectives}

1. To draw comparisons between the properties of palm family fiber materials

2. To assess satisfaction with utilization procedures of palm fibers

3. To make assessments concerning the effectiveness of palm family fibers on leaves

\subsection{Research Framework}

1. The framework for the testing of properties with fiber materials consists of the following: 1 ) Color properties of fibers; 2) Length properties of fibers; 3) Flexibility properties of fibers, and 4) Stickiness properties of fibers (Kasermbunyakorn, 2012).

2. The framework in three dimensions of balance that contribute to the development of sustainability in the context of future development consists of the following (Phraphromkunakorn, 2013):

> Balancing economics to add economic value from invaluable materials with the incomeearning method of value-added to be circulated in the product cycle again

$>$ Balancing social matters to bring stabilization and strength for human lifestyles in the communities and the local area with effectiveness

$>$ Balancing utilization development to represent friendliness to the environment and ecosystems contributing to positive effects by focusing on sustainable utilization

3. The framework creates the operational research pattern with people participation (PAR) by focusing on product development from palm leaves as the design research procedure in terms of social development or responding to people's requirements in local areas connecting Social Theory and Practical Theory or the new knowledge pattern integration (Sutthinarakorn, 2014), including arts, science, and social science (Baum et al., 2006).

$>$ Emphasizing the research procedure by focusing on change

$>$ Emphasizing the research procedure from the organic aspect

$>$ Emphasizing participation between researchers and group sampling for development through collaboration

\subsection{Methods}

1. The steps created for testing palm fiber properties of two types include:

> Testing of tensile properties for palm family fibers using a Tensile Testing Machine (Insron Model 5566) with speed ratios of $20 \mathrm{~mm} / \mathrm{min}$ according to the standard test; ISO 5079: 1995 (E)

$>$ Testing of colorfastness to rubbing according to ISO 105-X12:2001 by applying the Crock Meter machine to rub on a length of $10 \mathrm{~cm}$ as well as bringing the standard white cotton without using the rubbing cover with weight pressure of $900 \mathrm{~g}$ on the usage of the palm family weaving clothes with $14 \times 5 \mathrm{~cm}$ to be cut as an oblique line

2. Satisfaction Assessment for Fiber Quality from Four Types of Palm Family Leaves

$>$ The population is a group of people in the Khonsan Sub-District communities from 
Chaiyaphum Province totaling 162 people according to the community enterprise members for the year 2018 .

$>$ Group Sampling: the people in the Khonsan Sub-district communities from Chaiyaphum Province, amounting to 113 people, were selected by using multistage random sampling to gain an accepted discrepancy level of 5 percent according to the finished table of Krejcie and Morgan.

$>$ Research Tool: the study used structured questionnaires with content validity based on a 5-point rating scale assessment pattern to gain the reliability value and Cronbach's Alpha Coefficient at the level of 0.93 by using the data analysis of descriptive statistical values, such as mean, standard deviation, two-way ANOVA and independent t-tests (Cohen et al., 1989).

\section{Results and Discussion}

According to the collecting procedure of foliar parts from palm family leaves in the garden areas and fields for people in the community group to cultivate the palm family, it was clear that they always cultivated tan plants, coconut plants, oil palm plants, and betel nut plants by grouping together for collecting foliar parts. In addition, it showed the opinions on the requirements for bringing the valuable materials into their own communities by testing for fiber processing to manufacture for further utilization (Gorshkova et al., 2012). In this case, it includes applying for some materials to earn income for families and communities in terms of building increased stabilization. Thus, the people in the communities who joined together for palm fiber processing had average ages between $45-69$ years old; most of them were agriculturists or self-employed. As a result, this processing procedure development of palm fibers can be improved at a significant level with learning effectiveness in the communities and local areas from the first stage of the procedure.

Finally, it can be created for palm family fiber products based on the co-learning of people in the communities by emphasizing community areas with a focus on understanding the creation process and the development of the communities.

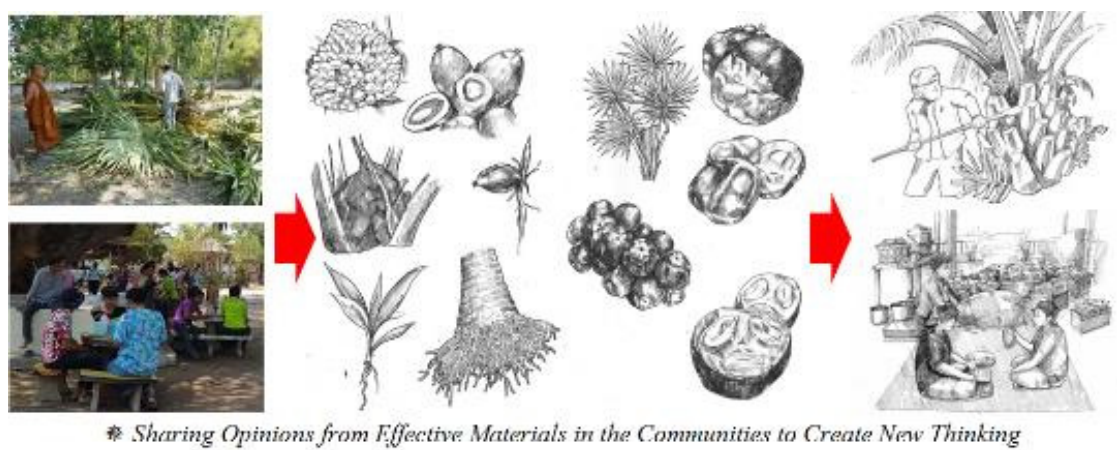

Fig. 2: Participation procedure for people and monks in the communities for learning with strength creation in future economics to communities

Source: Author

During the processing procedure of palm family leaves to gain fibers for industrial handmade works in the communities, it is necessary to apply the boiling procedure to peel off the tissue on four types of palm leaves until only the white surface remains. After that, it can be beaten until only the white surface inside the leaves is left before boiling again and peeling the tissues from the fibers, as shown in Figure 3. 


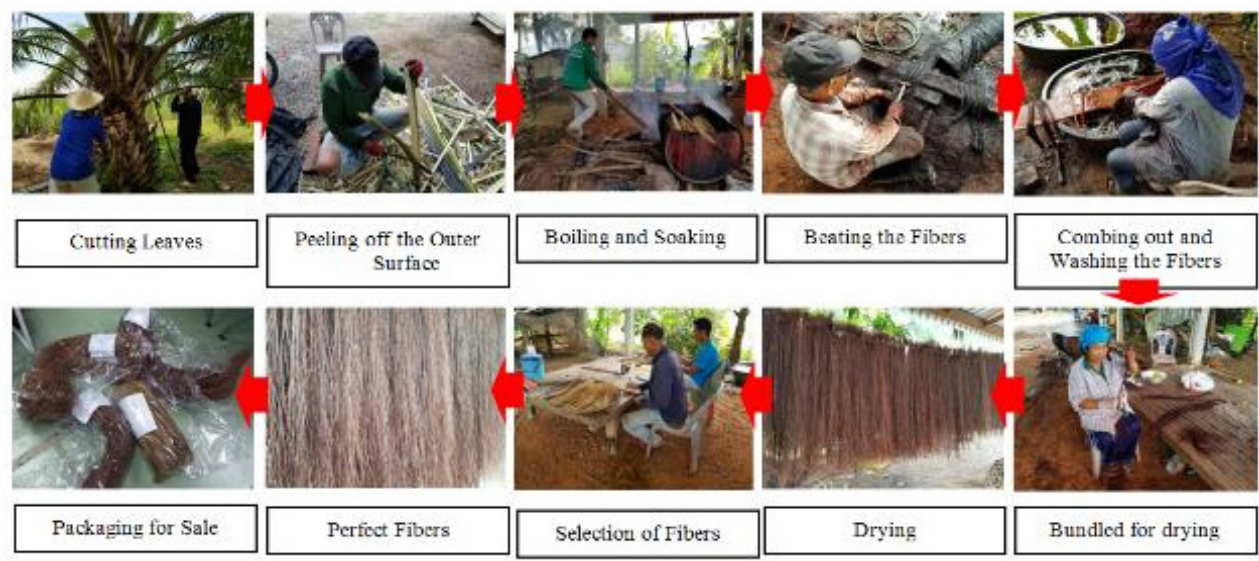

Fig. 3: Processing procedure for palm family fibers with people in communities Source: Author

Table 1: Drawing comparisons between the boiling procedure and soaking procedure for four palm types

\begin{tabular}{lccccc}
\hline & \multicolumn{3}{c}{ Measurement Unit per Hour $^{2}$} & \multicolumn{2}{c}{ Fiber Characteristics } \\
\cline { 2 - 6 } Type & Boiling Time $^{1}$ & Soaking Time $^{2}$ & Fiber Separation & Length & Color \\
\hline Oil Palm Fiber & 4.47 & 990 & 0.20 & $45-69 \mathrm{~cm}$ & Brown \\
\hline Coconut Fiber & 3.56 & 820 & 0.22 & $45-55 \mathrm{~cm}$ & Yellowish-White \\
\hline Betel Nut Fiber & 2.49 & 665 & 0.25 & $40-50 \mathrm{~cm}$ & Brown \\
\hline Tan Fiber & 4.32 & 876 & 0.22 & $46-68 \mathrm{~cm}$ & Purple Brown \\
\hline
\end{tabular}

Note: ${ }^{1}$ Boiling time with heat at 100 Celsius in water mixing of sodium hyperchloride $1 \%$

${ }^{2}$ Soaking time in water mixed with sodium hyperchloride $1 \%$

\section{Source: Author}

For palm family fibers under the boiling procedure to peel off the remaining fibers, it was shown that the betel nut fibers had to be boiled for 2.49 hours, while the coconut leaf fibers had to be boiled for 3.56 hours and the tan leaf fibers had to be boiled for 4.32 hours. Finally, the oil palm leaf fibers had to be boiled for the longest time at 4.47 hours. It was found that the longest boiling time resulted from the surface density of each type of palm leaf. In this case, the higher density on the leaf surface caused a longer boiling time.

For palm family fibers under the soaking procedure to peel off the tissues to leave only the fibers, the betel nut fibers can be soaked for 665 hours or 27.70 days. Similarly, soaking was applied for 820 hours or 34.16 days for the coconut leaf fibers, while the tan leaf fibers could be soaked for 876 hours or 36.50 days. Moreover, it was shown that the oil palm leaf fibers required the longest time at 41.25 days. Thus, the length of the soaking time depends on the type of palm leaf surface; if the internal surface for leaves has high density, it takes more time than usual. The separation of fibers will result in differences between the two learning methods. However, it is possible to beat the fiber from oil palm leaves into separation after using the boiling procedure or soaking procedure. Therefore, the betel nut leaves take the most time at twenty-five minutes, followed by the coconut fiber leaves and the tan fiber leaves at twenty-two minutes, and the oil palm leaves at twenty minutes. In this case, the fine fiber characteristics of the leaves inside the stems show it is possible to spend a longer time to beat the small fiber, ordered from the biggest size to the smallest, meaning oil palm leaf fibers, tan leaf fibers, coconut 
leaf fibers, and betel nut leaf fibers.

According to the opinions of the community group on learning about the fiber processing procedure, it was found to be a simple procedure without complexity. Besides, it is possible to easily boil and peel the fibers from palm family plants based on the materials from people's gardens. Similarly, the palm family fibers in the processing procedure maintained their beauty with a high level of abundance. Thus, the community group agreed to bring these natural fibers to be developed as creative products (Khan, 2009). Therefore, it is important to sustain effectiveness to weave the mats or clothes from nearby community groups before selling the palm family leaves to other communities. In this case, these fibers must add value or develop weaving skills or shaking skills, and so forth. This is considered the starting point to gather for manufacturing in a cluster pattern based on the potential as an outstanding subject in each community in terms of building up competitive opportunities in more markets (Phochathan, 2016).

According to the effectiveness testing results for palm family plants, it is possible to test the effectiveness of single fibers using a length of $6 \mathrm{~cm}$ by repeating the testing procedure ten times (Bacci \& Lonardo et al., 2011). Furthermore, it had the means for four types of palm family fibers, such as palm plants, betel nut plants, coconut plants, and tan plants including obtaining the means of the tensile ratios at the level of $58.47 \mathrm{~N}$, stretching ratios of the fiber means at the level of 6.87 percent, and the absorption phenomena of the fiber means at the level of $0.87 \mathrm{~g}$ to represent the testing details of the palm family fiber plants, as shown in Table 2.

Table 2:Comparison of four types of leaf fiber properties from palm family plants according to the testing standards of ISO 5079:1995(E) and strength testing to rubbing for the testing standard of ISO 105-X12:2001

\begin{tabular}{lccccc}
\hline & Tensile & Stretching & Absorption & \multicolumn{2}{c}{ Strength Level to Color Staining: Length } \\
\cline { 5 - 6 } Type & $(\mathrm{N})$ & $(\%)$ & $(\mathrm{g})$ & Wet Condition & Dry Condition \\
\hline 1. Fiber from Oil Palm Leaves & 57.19 & 7.30 & $\mathbf{0 . 6 2}$ & $3-4$ & 4 \\
\hline 2. Fiber from Coconut Leaves & 67.45 & 6.80 & 1.02 & $3-4$ & $3-4$ \\
\hline 3. Fiber from Betel Nut Leaves & 56.75 & 7.12 & 1.24 & 4 & $3-4$ \\
\hline 4. Fiber from Tan Leaves & 52.49 & 6.25 & 0.59 & 4 & $3-4$ \\
\hline Means of Fiber & 58.47 & 6.86 & 0.86 & - & - \\
\hline
\end{tabular}

Source: Author

According to the tensile testing of coconut leaves, the coconut fiber leaf tensile properties were at the level of $67.45 \mathrm{~N}$, followed by the oil palm leaf fiber tensile properties at the level of $57.19 \mathrm{~N}$, the betel nut fiber tensile properties at the level of $56.75 \mathrm{~N}$, and the tan fiber tensile properties at the level of 52.49 N. Thus, it can be explained that the four types of fibers of palm family leaves had effectiveness to gain high-level tensile properties as the tensile means were at the level of $58.47 \mathrm{~N}$.

The stretching testing of oil palm leaf fibers showed it was at the level of 7.30 percent, followed by betel nut leaf fibers at the level of 7.12 percent, coconut leaf fibers at the level of 6.80 percent, and tan leaf fibers at the level of 6.25 percent. In this case, it appeared that the palm family leaf fibers for the stretching means were at the level of 6.86 percent and the water absorption means were at the level of $0.86 \mathrm{~g}$.

According to the rubbing testing by using the peeling technique, it was found that the betel nut leaf fibers and tan leaf fibers were capable of enduring rubbing while getting wet and dry at the fourth level, or the excellent level, and at the fourth to third level, or a moderate to excellent level, followed by oil palm fiber leaves, which could endure rubbing while getting wet and dry at the third to fourth levels, or moderate to excellent levels. The coconut leaf fibers could endure rubbing while getting wet and dry at the fourth level or excellent level, and at the third to fourth levels, or moderate to excellent levels. 
According to the combination of weaving procedure with industrial work patterns in the communities, it can add economic value and beauty value from the communities' skills (Phaliewnich, 1999). Besides, it contributes suitably to the value of creative work from palm family fibers based on the effectiveness of clothes weaving skills and mat weaving skills in the communities. In this case, it can build up strength to transform the groups for manufacturing palm family fibers, and it should gain from the participation to show the opinions of people in the communities. Finally, the community group makes it possible to bring the cotton fibers to be woven because of the possibility of earning a lot of material in their local areas. In addition, it helps in measuring the greatest level for tensile properties according to cotton length at the level of $1593.13 \mathrm{~N} / \mathrm{cm}^{2}$ per percentage point and with the stretching ratios to the cotton length at the level of $11.67 \mathrm{~N} / \mathrm{cm}^{2}$ per percentage point from participation between communities. As a result, it contributes to product creation to gain a higher level of value from the leftover materials of the four types of palm family leaves in the communities (Malkapuram et al., 2008).

Table 3: Data integration from theory principle into creative thinking for development action and operational result in each step with continuity

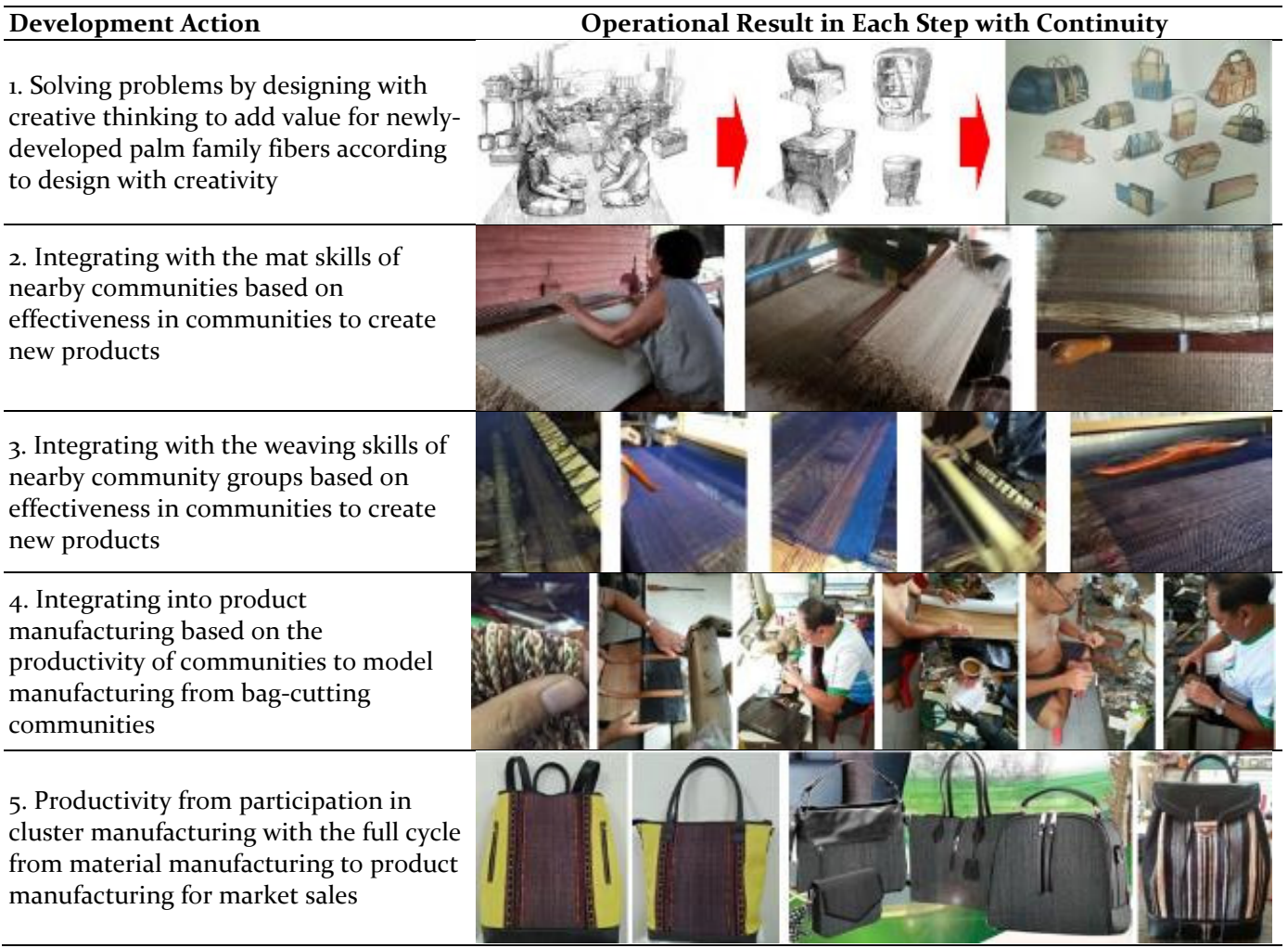

\section{Source: Author}

According to the community group, it manufactured the product models from palm family leaves based on the application of creative thinking to gain an increase in economic value. In addition, it is based on ladies' bag manufacturing, such as four suits or sixteen bags. In this case, all products were manufactured from palm family leaf fibers of different types using materials from local areas. After that, it is possible to add value by transferring sequin skills into the newly-designed ladies' bags, 
accounting for the addition of value to products. Thus, this value results from using the leftover material to be processed before being a selection of fibers and woven to become part of a model manufacturing process (Gowthaman et al., 2018).

Finally, this becomes the industrial handmade product development concept prior to bringing the fiber processing of new palm family leaf fibers and the new product models into the satisfaction assessment value step for people in the development community area (Intarachuto, 2016).

Table 4: Satisfaction of people in communities with palm family leaf fibers of different types $(\mathrm{n}=113)$

\begin{tabular}{lcccccc}
\hline \multirow{2}{*}{ Fiber } & \multicolumn{4}{c}{ Means (Standard Deviation) } & Satisfaction in \\
\cline { 2 - 6 } & Beauty & Strength & Forming & Processing & Sum & Processing \\
\hline 1. Palm Leaves & $3.98(0.68)$ & $4.08(0.70)$ & $4.19(0.61)$ & $4.04(0.69)$ & $4.07(0.67)$ & Excellent Level \\
\hline 2. Betel Nut Leaves & $3.67(0.60)$ & $3.19(0.68)$ & $3.39(0.78)$ & $3.16(0.64)$ & $3.35(0.71)$ & Moderate Level \\
\hline 3. Coconut Leaves & $4.25(0.62)$ & $4.41(0.57)$ & $4.60(0.49)$ & $4.61(0.49)$ & $4.47(0.56)$ & Excellent Level \\
\hline 4. Tan Leaves & $4.61(0.49)$ & $4.61(0.49)$ & $4.27(0.66)$ & $4.47(0.58)$ & $4.49(0.57)$ & Excellent Level \\
\hline Totals & $4.13(0.69)$ & $4.07(0.82)$ & $4.11(0.78)$ & $4.07(0.83)$ & $4.10(0.78)$ & Excellent Level \\
\hline
\end{tabular}

Note: $F=11.450 ; d f=9 ; p$-value $=0.00$

\section{Source: Author}

According to the results of the analysis from the group sampling, the members of the community group responsible for palm family leaf fiber processing development total 113 people. In addition, it was found that the overall satisfaction with palm family leaf fibers was at an excellent level (Mean= 4.10, S.D.= o.78) according to the members in the case study of Khonsan Sub-District from Chaiyaphum Province. Specifically, tan leaves had satisfaction at the excellent level (Mean $=4.49$, S.D. $=0.57$ ), coconut leaf fibers had satisfaction at the excellent level (Mean $=4.47$, S.D. $=0.56)$, palm leaf fibers had satisfaction at the excellent level (Mean $=4.07$, S.D.= 0.67), and betel nut leaf fibers had satisfaction at the moderate level (Mean $=3.35$, S.D. $=0.71$ ). Thus, the satisfaction results appear to show conformity with the four types of palm family leaf fibers for the community group's acknowledgment to know about the fiber properties, for which beauty was considered the main property. Finally, each group's agreement about the four types of fibers showed the beauty in the variety of pattern forming.

According to the analysis of the results for satisfaction with the fiber properties in four fields, it was shown that the palm family leaf fibers had the greatest satisfaction overall for beauty at the excellent level (Mean = 4.13, S.D. $=0.69)$ and also fiber-forming at the excellent level (Mean= 4.11, S.D. $=0.78)$, while strength and fiber processing were also at the excellent level (Mean=4.07, S.D. $=0.82$; 0.83 ).

In this case, the satisfaction assessment results showed that the palm family leaf fibers had a prominent point in beauty with smooth fiber properties in the formation. Moreover, the fiber processing procedure showed some problems occurred from several procedure steps with the essential need to use human labor as the main point. Therefore, it may impact satisfaction management at a lower level than other assessment results when considering Levene's test. Finally, it was found that the value of $\mathrm{p}$ was equal to 0.00 and had the types and properties of palm fibers at varied levels with significance.

Table 5: Analysis results from two-way variances of palm family leaf fibers of different types in four fields

\begin{tabular}{lccccc}
\hline Variance Source & SS & df & MS & F & P \\
\hline 1. Fiber Type of Palm Family Plants & 381.04 & 3 & $\mathbf{1 2 7 . 0 1}$ & 330.53 & 0.00 \\
\hline 2. Properties of Palm Family Fibers & 1.179 & 3 & 0.39 & 1.02 & 0.38 \\
\hline Interaction & 39.60 & 9 & 4.40 & 11.45 & 0.00 \\
\hline Residual & 688.61 & 1792 & 0.38 & & \\
\hline${ }^{*}$ E E lt; 0.05 & & &
\end{tabular}

Source: Author 
According to the influencing test for the types of factors of palm leaf fibers, it was found that $\mathrm{F}$ was equal to 330.53; Sig. was equal to o.oo and the leaf fibers of at least one type differed from other leaf fibers with significance. In addition, the analysis of the results with one-way ANOVA of fiber factors showed that coconut leaf fibers and tan leaf fibers had the same properties with significance, while other fiber factors were shown to involve different properties.

According to the above information, it was found that there was similarity between coconut leaf fibers and tan leaf fibers in terms of total satisfaction. In this case, it is related to the beauty, strength, forming, and processing with different means of satisfaction at only 0.25 . Therefore, it influenced coconut leaf fibers and tan leaf fibers to gain similar properties in physical fields and their applications.

According to the influencing test on palm family leaf fiber properties in each type, it was found that $\mathrm{F}$ was equal to 2.02; Sig. was equal to 0.38 , which included the findings for the four types in the same way with statistical significance for the fiber property factors.

According to the summary of the influencing test results for palm family leaf fibers and fiber properties in each type, it was found that F was equal to 11.45; Sig. was equal to o.oo and included at least one type of palm family leaf fiber. Each type of fiber property was different from other palm fiber types with statistical significance. Similarly, it was found that there were different properties between coconut leaf fibers and tan leaf fibers. However, these fiber types had some criteria offering the same properties as palm fibers and betel nut fibers. In this case, it showed the beauty of fibers with long processing procedures due to their small size with high resolution when considering the means for satisfaction with the processed palm leaf fibers and the processed betel nut fibers. In the same way, these fibers still had physical properties that made it difficult to peel them. Therefore, the community must use effort over longer periods than in the case of coconut leaf fibers and tan leaf fibers.

Additionally, importance should be given to the processing of the leaves as an essential step for the fiber processing to be formed suitably in products (Biagiotti et al., 2004). According to the results from the satisfaction assessment, this relies on the community group using palm family leaf fibers for creating model products that are ready for market sales.

Besides, the development community group is able to manage effectively, consisting of four types.

$>$ Effectiveness from materials by bringing the leftovers from the four types of palm family leaves in their agricultural areas to apply as materials without seeing a lack of value.

$>$ Effectiveness in handmade work skills by bringing their skills transferred from the community to be developed for fiber processing in terms of being the product creators, together with using technical skills for adding value.

DEfectiveness in human labor by bringing the people's labor to apply in supplementary careers for the communities, which build up strength with income as well as creating the economic strength to gain more incentives.

$>$ Effectiveness in life stabilization by bringing added value for applying to resources which appear to lack value in their agriculture areas, contributing to more stable incomes as well as reducing the need for people to come to apply for jobs in the city. This strengthens the family and reduces the movement of industrial labor to big cities as a result.

It can be explained that the procedure of development applying the four types of palm family leaf fibers has a positive effect on society and the surrounding environments. In addition, it can support the application of community intellect and skills in the local area to become the main factors for creating model products that respond to market requirements and customer needs in suitable ways. As a result, it is possible to present the product models made from palm family leaf fibers with gains in effectiveness for the model community group. 

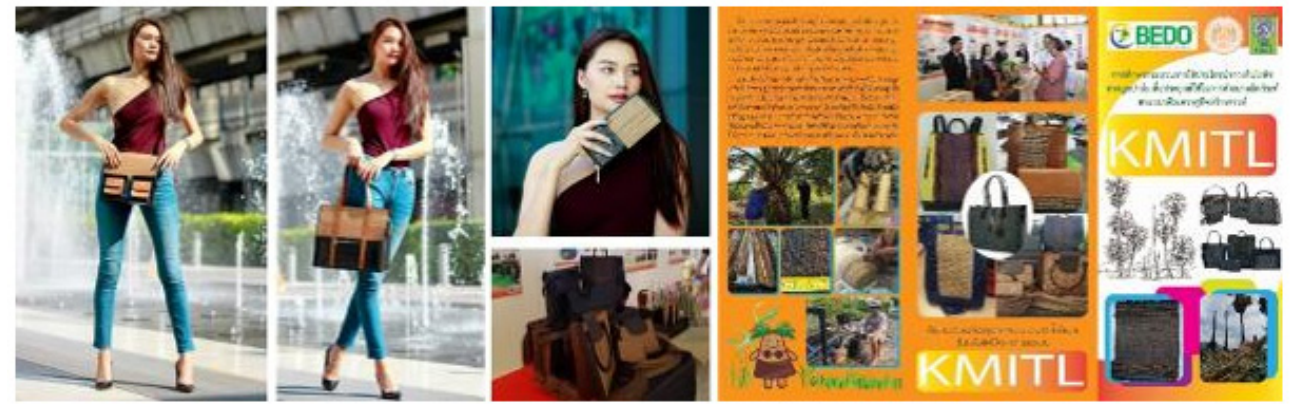

Fig. 4: Model products made from palm family leaf fibers and documents to transfer knowledge into society

Source: Author

A comparison of the products made from new palm family leaf fibers and the products made from palm family tree materials in the markets can be represented by comparing the results shown in Table 6.

Table 6: Comparing results for new and old products made from components of palm family plants

\begin{tabular}{lccccc}
\hline Comparing Group & N & Mean & Std. Deviation & Std. Error & Mean Satisfaction Level \\
\hline Products Made from New Palm Fibers & 113 & 4.30 & 0.693 & 0.065 & Excellent Level \\
\hline Products Made from Old Palm Family Plants & 113 & 3.28 & 0.861 & 0.081 & Moderate Level \\
\hline
\end{tabular}

Source: Author

According to the assessment of products made from new palm family leaf fibers, they were found to achieve an excellent level of satisfaction, (Mean = 4.30, S.D.= o.69), while the products made from old palm family plants were at a moderate level of satisfaction, (Mean $=3.28$, S.D. $=0.86$ ). Subsequently, the F-test was performed along with Equality of Variances by checking with the population variance and starting the real test.

Table 7: Variance testing of group sampling data

\begin{tabular}{|c|c|c|c|c|c|c|c|c|c|}
\hline \multirow{3}{*}{ Variance } & \multicolumn{2}{|c|}{$\begin{array}{c}\text { F-test for Equality } \\
\text { of Variances }\end{array}$} & \multicolumn{7}{|c|}{$\begin{array}{c}\text { t-test for } \\
\text { Equality of Means }\end{array}$} \\
\hline & \multirow[t]{2}{*}{ F } & \multirow[t]{2}{*}{ Sig. } & \multirow[t]{2}{*}{$\mathrm{t}$} & \multirow[t]{2}{*}{$\mathrm{df}$} & \multirow[t]{2}{*}{$\begin{array}{l}\text { Sig. } \\
(2 \text { tailed })\end{array}$} & \multirow[t]{2}{*}{$\begin{array}{c}\text { Mean } \\
\text { Difference }\end{array}$} & \multirow[t]{2}{*}{$\begin{array}{l}\text { Std. Error } \\
\text { Difference }\end{array}$} & \multicolumn{2}{|c|}{$\begin{array}{l}95 \% \text { Confidence } \\
\text { Interval of the } \\
\text { Difference }\end{array}$} \\
\hline & & & & & & & & Lower & Upper \\
\hline $\begin{array}{l}\text { Equal Variance assumed } \\
\text { Equal Variance not assumed }\end{array}$ & 1.542 & 0.216 & $\begin{array}{l}9.79 \\
9.79 \\
\end{array}$ & $\begin{array}{c}224 \\
214.24\end{array}$ & $\begin{array}{l}0.000 \\
0.000\end{array}$ & $\begin{array}{l}1.018 \\
1.018\end{array}$ & $\begin{array}{l}0.104 \\
0.104\end{array}$ & $\begin{array}{l}0.812 \\
0.812\end{array}$ & $\begin{array}{l}1.223 \\
1.223 \\
\end{array}$ \\
\hline
\end{tabular}

Source: Author

It was apparent that the F-test was equal to 1.542, while the Sig. Value was equal to 0.216. The Critical Value was 0.05 and the F-table Value was equal to 3.883, including the testing of the variance value of populations. 
Table 8: Test for drawing comparisons with the satisfaction of the group sampling for new and old products

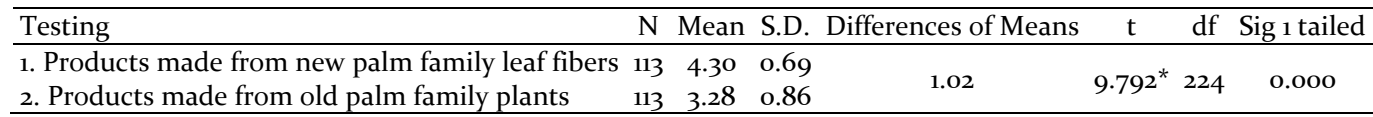

Source: Author

According to the testing results after drawing comparisons with the satisfaction results from the group samplings, it was found that the difference of means was at the level of 1.02. In addition, it was found that the means of satisfaction for the products made by new palm family leaf fibers were at a higher level than the old palm family plants when tested using t-test statistics at a significance of .05.

When the products made from new palm family leaf fibers were at a satisfactory level from community people in agreement with the manufacturing effectiveness, it makes it possible to bring the manufacturing products made from palm family leaf fibers into general publication for the public. After that, the publication procedure can commence with public relations covering the new knowledge of the palm family leaf fiber processing and new product patterns. Thus, it can present the products into the markets, representing the uniqueness of palm family fibers through their beauty and effectiveness. The research team was given kind support by Her Royal Highness Princess Maha Chakri Sirindhorn to report the results of research on palm leave fiber products in front of Her Royal Highness at Chulachomklao Royal Military Academy.
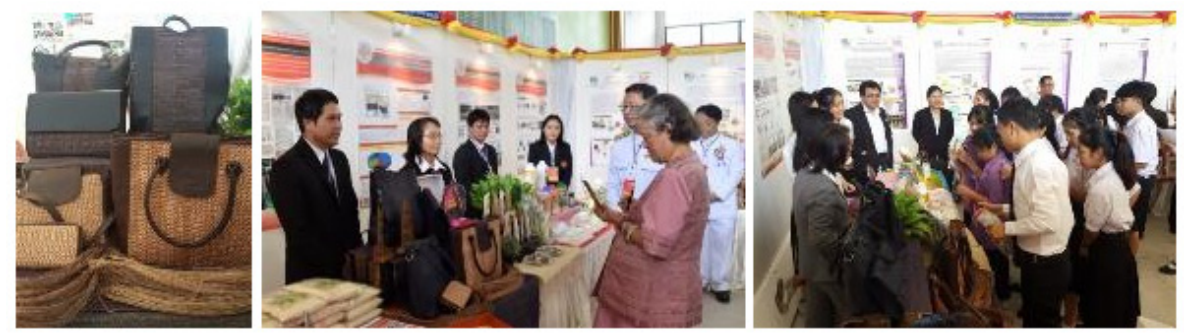

Fig. 5: Reporting on research in front of Her Royal Highness Princess Maha Chakri Sirindhorn at Chulachomklao Royal Military Academy

Source: Author

\section{Conclusion}

In line with good effectiveness to develop commercial handmade products for adding value to palm family leaves, the approach brought leftover resources from agricultural areas in each harvest season with removal ratios at more than 12 leaves per tree. In this case, it is possible in quantitative research to apply the leaf fiber processing procedure for the four types by gaining effective tensile properties according to the ISO 5079:1995(E) testing procedure. Thus, it is suitable to be applied for constructing commercial handmade products because of the energy processing ratios from the leaf fibers, which are more or less even. Furthermore, the physical characteristics of the smooth fibers and the beautiful colors with good uniqueness mean it represents a high weight for one line in the fiber. In this case, it is considered a potential fiber to apply for product design and furniture design, effectively conforming to the development of sustainability aims by using such components (Tamilmani \& Pawar, 2020; Mantas Markauskas \& Asta Baliute, 2020). 


\begin{abstract}
"The operational research is involved with the community participation (PAR) for the learning method of effectiveness with materials, skills and intellects, and others. Subsequently, it can be promoted for gaining product development patterns by building up the economic occupation strength and community lifestyles. Finally, it is capable of managing sustainability in a suitable way." (Phattarawat, 2010)
\end{abstract}

According to the application of the concept for operational research procedures, it helps to fulfill the knowledge with design to build social strength by responding to the local people. In this case, it assists in supporting development by focusing on the development of sustainability within the research guidelines for community participation.

"The operational research with participation is a method for people in communities to join in the experience of learning based on the strength of participation by every party when doing activities. It begins with defining the problem, the management, and the data analysis, as well as the solution guidelines with activity promotion." (Chatawanit, 2004)

According to the results of the newly-developed palm family leaf fibers, these conform to the motoric action of communities as a real-learning step from joining the community group (Kemmis, 2006). In this case, it was managed through the gathering of data based on people's ability in the communities with the driving concepts for procedure development and new product design. Therefore, it assists in control with the directions of the testing procedures as the clear comparison to be suitable with social and local environments along with the alterations of requirements (Lewin, 1946).

Based on the management of newly-developed palm family fibers, the people in communities were able to discover their own effectiveness in bringing the local materials to be applied. In this case, it should be developed from material that appears to lack value so that it can become valuable, as well as adding more economic value and improving the capability by applying the palm family leaf fibers to gain effective participation from nearby community groups. Therefore, suitable intellect is used to weave the mats and cloth with cluster development in terms of building up the commonality. In this case, it could be the development characteristics from the community groups of the upstream and downstream manufacturers (Kuah, 2002; Fatos Ukaj, 2019). According to participation management between communities, the results can be explained as the capability to sustainably compete with the rest of the world (Frank et al., 2016; Ronald Glasberg, 2019), including the aspects of productivity and innovation improvement with friendliness in nature.

Based on the four types of palm family leaf fibers, these are involved with the members in the model community group of Khonsan Sub-District in Chaiyaphum Province. Moreover, satisfaction with the fibers is reported in order from the highest to the lowest level: tan leaves, coconut leaves, oil palm leaves, and betel nut leaves. In this case, the testing results with the standard procedures of tensile tests under ISO 5079:1995(E) showed the suitability of palm leaf fibers for application with commercial handmade characteristics (Dai and Fan, 2010). Thus, it conforms with the concept of effectiveness for development with natural fibers in a creative context (Narkpiban \& Poonsawat, 2020).

"The fibers were brought into the development of industrial handmade works with suitability in several fields, namely: 1. Color property of fibers, 2. Length property of fibers, 3. Width property or diameters of fibers, and 4. Stickiness property of fibers." (Kasermbunyakorn, 2011)

According to the factor assessment of the four types of palm fibers consisting of beauty, strength, formation, and processing, they were represented by the same levels of significance. In this case, the concept of palm leaf fibers showed they had a smooth shape that could be separated with fiber beating (Chanyatham \& Sikkha, 2012). Similarly, it was found that coconut tree fibers and tan tree fibers did not differ in terms of beauty, strength, ease of formation, or processing when considering the influence of palm family fibers and properties. Therefore, the people in the communities had the same opinions and similar levels of satisfaction, conforming to the creative idea of commercial handmade products based on local intellect with participation in a sustainable way (Anand \& Sen, 1994; Willer H. \& Lernoud 
J., 2019; Sandro Serpa et al., 2020).

\begin{abstract}
"According to the application of procedures to make community alterations, it should be considered from the effectiveness of original lifestyles. In this case, it integrates with sufficient technologies to gain the participation of community members to become the accepted feeling of new technologies from now on (Deebunmee Na Chumphae, 2007; Teerapong Poti et al., 2020)."
\end{abstract}

Consequently, bringing the model products made from palm family leaf fibers to create new products had a satisfaction level of effect on the people's group at a significantly higher level than existing palm family plants. Thus, it is considered a result that conforms with community readiness (Phriwanrat, 2020; Buranasing, N., 2015). In this case, it is concerned with the exposure of potential for new palm family leaf fibers, including the community development of natural fibers manufactured as materials for weaving mats or doing basketry work in nearby areas. Thus, it is possible to develop their own commercial handmade products inside the community group with suitable properties for weaving or forming materials (Kaewka T., 2019; Venerable Phra Brahmagunabhorn, 2013; Itang Ede Egbung \& Jayne Owan, 2019).

The fibers had a long length with flexibility. These properties are important for the effectiveness of palm family leaf fibers when used for the development of commercial handmade products in communities. Significantly, it becomes the beginning point to gain a sustainable development pattern for human lifestyles with the expression of friendliness in community areas.

\title{
5. Acknowledgements
}

This research was carried out using funding for research and annual development in the fiscal year of 2017 for investment purposes. Significantly, it aimed to focus on economic development with the biomass variety of the Biodiversity-Based Economy Development Office to join with King Mongkut's Institute of Technology Ladkrabang.

\section{References}

Adrian T.H. Kuah (2002). Cluster Theory and Practice: Advantages for the Small Business Locating in a Vibrant Cluster. Journal of Research in Marketing and Entrepreneurship, 4(3), $206-228$. https://doi.org/10.1108/14715200280001472

Al-Khayri, J. \& C. Niblett (2012). Envision of an International Consortium for Palm Research. Emirates Journal of Food and Agriculture, 24(5), 470-479.

Anand, S. \& Sen, A. K. (1994). Sustainable human development: Concepts and priorities. Occasional Paper 8, Human Development Report Office, New York: United Nations.

Bacci, L., S. D. Lonardo, L. Albanese, G. Mastromei, \& B. Perito (2011). Effect of different extraction methods on fiber quality of nettle. Textile Research Journal, 81(8), 827-37. https://doi.org/10.1177/004051751 0391698.

Baum F., MacDougall C. \& Smith D. (2006). Participatory action research. Journal of Epidemiology E Communities Health, 6o(1), 854-857. https://doi.org/10.1136/jech.2004.028662

Biagiotti J, Puglia D \& Kenny J.M. (2004). A Review on Natural Fiber-Based Composites-Part I. Journal of Natural Fibers, 1(2), 37-68. https://doi.org/10.1300 / J395Vo1no2_04

Buranasing N. (2015). Oil Palms as Agriculture Products for Electric Manufacturing. Bangkok, Office of Academic Affairs for Secretariat of the House of Representatives.

Chanyawan, Chanyatham \& Sikkha, Phrathubchai (2012). Fiber development from Nypa Palm with being applied for the product design. AJNU Academic Journal from Arts Architecture in Naresuan University, 3(1), 72-82.

Chantawanich, S. (2003). Data Collection Method for Quality Research. Bangkok, Research and Development Institute in Khon Kaen University.

Chuthathip, Phattarawat (2010). Action Research Manual. Bangkok, Kasetsart University in Faculty of Economics of Cooperative Economics Institute.

Cohen, S.M., Bronner, G., Kuttner, F., Jurgens, G. \& Jackle, H. (1989). Distal-less encodes a homeodomain protein required for limb development in Drosophila. Nature, 338(1), 432-434. https://doi.org/10.1038/338432ao 
Dai, D. \& M. Fan (2010). Characteristics and performance of elementary hemp fiber. Materials Sciences and Applications, 1(6), 336-42. https://doi.org/10.4236/msa.2010.16049.

Deebunmee Na Chumphae, S. (2007). Industrial Product Design. Bangkok, Odian Store Publishing.

Evgeny V. Frank, Oksana V. Mashevskaya \& Lilia V. Ermolina. (2016). Innovational Mechanism of Implementation of Cluster Initiatives in Business. European Research Studies, 19(1): 179-188.

Fatos Ukaj (2019). Market Regulation and Marketing of Enterprises as a Factor for the Development of SMEs in Kosovo. Academic Journal of Interdisciplinary Studies, 8(1), https://doi.org/10.2478/ajis-2019-0004

Gowthaman, S., Nakashima, K. \& Kawasaki, S. (2018) State-of-the-Art Review on Soil Reinforcement Technology Using Natural Plant Fiber Materials: Past Findings, Present Trends, and Future Directions. Materials, 11(1), 553-564. https://doi.org/10.3390/ma11040553

Intarachuto, S. (2009). Reuse, The Art Of Reclaim. Bangkok, Phabunma Publishing Company Limited.

Itang Ede Egbung \& Jayne Owan. (2019). Literacy and the Girl-Child Empowerment for Sustainable Development: A Study of Amma Darko's Faceless. Mediterranean Journal of Social Sciences, 10(60), 10-16, https://doi.org/10.36941/mjss-2019-0074

John Karkazis \& Georgios C. Baltos (2018). The Geo-economic Gravity Systems as a Tool for the Analysis of SocioEconomic Polarization in a Society: Country Case Study and Geographic Information Modeling Explain Longterm Transformation Potential towards Increased Regional Attractiveness and Efficiency. Academic Journal of Interdisciplinary Studies, 7(2), 129-136, https://doi.org/10.2478/ajis-2018-0054

Kadolph, S.J. \& Langford, A.L. (1998). Textiles. New Jersey, Prentice-Hall, Inc.

Kaewka, T. (2019). Daily Public Relations on 27 August 2019. Bangkok, National News Bureau of Thailand.

Kasermbunyakorn, S. (2011). Natural Colors with Movements of Conserved Textiles. Economics Journal, 55(1), $63-65$.

Kemmis, S. (2006). Participatory action research and the public sphere. Educational Action Research, 14(4), 459-476. https://doi.org/10.1080/o9650790600975593.

Khan, G. (2009). Estimation of main constituents of Ananus comosus (pineapple) leaf fiber and its photo-oxidative degradation. Journal of Natural Fibers, 6(2), 138-150. https://doi.org/10.1080/154404709 02955369

Lewin, K. (1946). Action Research and Minority Problems. Journal of Social, 2(4), 34-46.

Malkapuram R, Kumar V. \& Yuvraj S. N. (2008). Recent Development in Natural Fiber Reinforced Polypropylene Composites. Journal of Reinforced Plastics and Composites, 28(1), $1169-1189$. https://doi.org/10.1177/0731684407087759

Mantas Markauskas \& Asta Baliute (2020). Modeling Technological Progress Evaluation: Case of Lithuanian Manufacturing Industry. Mediterranean Journal of Social Sciences, 11(6), 1-11, https://doi.org/10.36941/mjss2020-0058

Narkpiban, Koranat \& Poonsawat, Thiprada (2020). Optimizing Cellulose Extraction from Kenaf (Hibiscus Cannabinus L.) Fiber by Selective Retting and Hydrothermal Pretreatment. Journal of Natural Fibers, 14(1), https://doi.org/10.108o/15440478.2020.1758982

Na Takuathung, P., Saribud, U. \& Egwutvongsa, S. (2015). Materials from Oil Palm Fibers for Product Design. Industrial Education Journal, 14(12), 87-99.

Nuankhae Phaliewnich (2542). Knowledge of Clothes and Fibers. Bangkok, SE-EDUCATION Public Company Limited.

Office of Agricultural Economics (2019). Economic report in Quarter 2 of 2019. Bangkok, Agricultural Development Policy and Planning Division from Office of Agricultural Economics.

Phriwanrat, K. (2020). The Research and Development of Tie-Dyed Handicraft Products From Krabi Province for The Designing of Ko Klang Communities' Contemporary Souvenirs, Leading Krabi Province to Become a Creative City. Humanities, Arts and Social Sciences Studies, 20(1), $119-137$. https://doi.org/10.14456/hasss.2020.6

Phochathan, S. (2016). Capability Development of SMEs through Cluster-based Approach: Healthy Food Industrial Cluster in Nakhon Ratchasima Province. Ratchaphruek Journal, 14(2), 46-52.

Ronald Glasberg (2019). How to be Wise without Being a Wise-Guy: Developing the 'Infi-Net'. Academic Journal of Interdisciplinary Studies, 8(3), https://doi.org/10.36941/ajis-2019-00o1

Sandro Serpa, Carlos Miguel Ferreira \& Maria José Sá. (2020). Influencing Factors of Audit Report Lag: Evidence from Indonesia. Academic Journal of Interdisciplinary Studies, 9(4), doi: https://doi.org/10.36941/ajis-20200065

Sutthinarakorn, W. (2014). Participatory Action Research: PAR and Realization process. Bangkok, Pimsiam Publishing Company Limited.

Teerapong Poti, Somchai Seviset \& Songwut Ekawutwongsa (2020). Study and Development of the Process of Converting the Postal Jacket to Deteriorate for Apply to Products. Mediterranean Journal of Social Sciences, 11(4), 102-111, https://doi.org/10.36941/mjss-2020-0045 
Tamilmani, Gobi Kannan \& Pawar, Suryappa (2020). Development and Characterization of Sisal Fiber and Wood Dust-Reinforced Polymeric Composites. Journal of Natural Fibers, https://doi.org/10.1080/15440 478.2019.1710649

Tatyana Gorshkova, Nina Brutch, Brigitte Chabbert, Michael Deyholos, Takahisa Hayashi, Simcha Lev-Yadun, Ewa J. Mellerowicz, Claudine Morvan, Godfrey Neutelings \& Gilles Pilate. (2012). Plant Fiber Formation: State of the Art, Recent and Expected Progress, and Open Questions. Critical Reviews in Plant Sciences, 31(3), $201-228$. https://doi.org/10.1080/07352689.2011.616096.

Venerable Phra Brahmagunabhorn (2013). Sustainable Development. Bangkok, Komol Foundation Publishing.

Willer, Helga \& Lernoud, Julia (2019). The World of Organic Agriculture. Statistics and Emerging Trends 2019. Research Institute of Organic Agriculture FiBL and IFOAM Organics International, Switzerland, Frick and Bonn. 